\title{
When Phonology Undergenerates: Evidence from Asturian Enclitic Structures
}

\author{
FRANCISCO J. FERNÁNDEZ-RUBIERA \\ University of Central Florida ${ }^{1}$
}

\section{$1 \quad$ Introduction}

Asturian, a Western Iberian Romance language that remains underrepresented in syntactic descriptions both traditional and current, exhibits similar enclisis/proclisis alternations as those found in Galician and European Portuguese in the matrix environment. Consider the example in (1), which is only grammatical when enclisis arises, which contrasts with that in (2), which may only exhibit proclisis ${ }^{2}$.

(1) Téoles tayaes [*Les teo]

have1SG-themCL cut

'I have them (my hands) cut.'

[Álvarez, Llames]

(2)
Nun me mancó
[*mancóme]
not meCL hurt3SG
'S/he didn't hurt me.'

[Orton, Mayordomu]

Microparametric differences arise the moment we turn our attention to the finite embedded context. Asturian, but neither Galician nor European Portuguese, may either exhibit optional enclisis in a subordinate context as that in (3), or obligatory enclisis in a finite embedded environment as that illustrated in (4).
a. Digo [qu'ayúdame] say1SG that-help3SG-IND- meCL
b. Digo [que me ayuda] say1SG that meCL help3SG-IND
'I say that s/he helps me out.'

[From Viejo (2008)]

\footnotetext{
I would like to thank Adolfo Ausín, Héctor Campos and Elena Herburger for their continuous help and support, Xulio Viejo and Ramón d'Andrés for their time and help with data and judgments in Asturian, and the audiences at the $20^{\text {th }}$ Colloquium on Generative Grammar (Spain, 2010), at the Challenging Clitics Workshop (Oslo, 2011) and at the $40^{\text {th }}$ Annual Meeting of the Berkeley Linguistics Society (California, 2014) for comments and suggestions. Needless to say, I am solely responsible for the use I made of their comments.

2 The clitic is bold-faced in this and subsequent examples for the reader's convenience. The abbreviations used in the glosses are the following: CL (Clitic), IND (Indicative mood), INF (Infinitival), PL (Plural), RFL (Reflexive), SG (Singular), 1/2/3 (First, second and third person respectively).
} 
Yera tan pija [que llamábenla Bambi] [*la llamaben] was3SG so preppy/posh that called3PL-IND-herCL Bambi

'She was so preppy/posh that they used to call her Bambi.'[From TV Series "El Chigre"]

The availability of an enclitic pattern in these environments, unexpected under a phonological analysis to clitic placement alternations as those discussed, is accounted for assuming that enclisis arises independently of phonological factors. Extending the analysis proposed in Fernández-Rubiera (2014), I argue that enclisis arises as a result of Fin(iteness) ${ }^{\mathbf{o}}$ (Rizzi 1997 and subsequent) being a phase-head (Chomsky 2008 and subsequent) triggering lastresort verb-movement in the absence of A'-movement or a closer head to Fin ${ }^{\circ}$ than $\mathrm{T}^{\mathrm{o}}$. As I will show, this analysis not only accounts for enclisis/proclisis alternations in the matrix and subordinate environments in Asturian, but it also explains naturally the correlation between these clitic placement alternations and the interpretation they give rise to in the subordinate environment.

This paper is organized as follows. I first introduce some basic data showing the different contexts that trigger enclisis and proclisis in the matrix environment in Asturian in section 2. In section 3, I discuss how phonological approaches to clitic placement alternations as those in Asturian have been accounted for, ultimately showing how they fall short at explaining the enclisis we find in (3a) and (4). I lay out my main assumptions and my analysis in section 4, and I show how the analysis I propose accounts for enclisis/proclisis alternations in matrix environments in section 5, and in section 6 I extend the analysis to account for the observed clitic patterns we find in Asturian in finite embedded contexts as those in (3) and (4). Further predictions and evidence for the analysis I propose are discussed in section 7 , related to the interpretation that these different clitic patterns correlate with in the finite embedded context, and section 8 concludes this paper with further questions.

\section{The Data: Enclisis and Proclisis Alternations in Matrix Environments in Asturian}

\subsection{Enclitic Patterns in the Matrix Environment in Asturian}

Similarly to what we find in Galician and European Portuguese, enclisis arises in Asturian in verb-initial contexts, with preverbal non-quantified subjects, and after Clitic Left-Dislocated Topics. These different environments are illustrated in the examples below, and the source of the examples is given in brackets.

Téoles tayaes [*Les teo]
have1SG-themCL cut
'I have them (my hands) cut.'

[Álvarez, Llames] 
El xenru matóse nun accidente na mina

the son-in-law killed3SG-rflCL in-an accident in-the mine

'His son-in-law got killed in an accident in the mine.'

[*Se mató]

[González, Comedies]

(7)

Eso $_{\mathrm{i}}$ sábeslo $_{\mathrm{i}} \quad$ per lleer les cartes [ ${ }^{*}$ Lo sabes]

that know2SG-itCL for read-INF the cards

'That, you know it from reading the (tarot) cards.'

[González, Comedies]

The environments where proclisis arises in the matrix environment in Asturian are shown next.

\subsection{Proclitic Patterns in the Matrix Environment in Asturian}

A proclitic pattern shows up in Asturian with the negative marker, and with preverbal $w h$ - and Focus constituents ${ }^{3}$, as illustrated in the following examples. These contexts also trigger proclisis in Galician and European Portuguese.
Nun me mancó
[*mancóme]
not meCL hurt3SG
'S/he didn't hurt me.'

[Orton, Mayordomu]

(9)
Cómo t'atreves?
[*atréveste]
how rflCL-dare2SG
'How dare you?'

[Rodríguez Medina, Gaviotes]

YO MESMA me la repito un cientu vegaes [*repítomela]

I self rflCL-itCL repeat1SG one hundred times

'I myself repeat it to myself one hundred times.'

[de Pablo, Memoria]

\subsection{Enclisis and Proclisis in the Matrix Environment in Asturian: A Summary}

Summarizing, and similarly to what we find in the other Western Iberian Romance languages (e.g., Galician and European Portuguese), enclisis arises in the matrix environment in Asturian in verb initial contexts, with preverbal non-quantified subjects and after Clitic Left-Dislocated Topics. Proclisis, on the other hand, shows up in the matrix environment with the negative marker, and with preverbal wh- and Focus constituents.

\footnotetext{
As it is customary, capitals are used to indicate the rising (Focus) intonation of the fragment yo mesma, "I myself."
} 
In what follows, I will show how phonological approaches to clitic placement alternations as those illustrated above fall short at explaining the availability of enclisis in the finite embedded context in Asturian.

\section{Phonological Accounts of Enclisis/Proclisis Alternations}

\subsection{Accounting for Enclisis and Proclisis in the Matrix Environment}

Rivero (1986), Campos (1989), and Barbosa (1995, 2000) argue that clitics in Old Spanish, Galician, and European Portuguese respectively are sensitive to phonological filters as those in (11) and (12).

(11) $*\left[\mathrm{CP} \quad \varnothing\right.$ clitic $\left._{[\mathrm{ENCLITIC}]}\right]$, where $\varnothing=$ another clitic or a null element [Rivero (1986)]

$$
\text { *[IntP cl(itic) V... ], where IntP = Intonational Phrase } \quad \text { [Barbosa }(1995,2000)]
$$

For Rivero (1986), the filter in (11) triggers last-resort $\mathrm{T}^{\mathrm{o}}$-to- $\mathrm{C}^{\mathbf{o}}$ movement. Thus, an example as that in (5), repeated in (13) below, is derived as in (14). Rivero assumes that the clitic raises to TP past the verbal head (cf. (14a)), operation after which the clitic appears as the first element in the structure (cf. (14b)), $\mathrm{T}^{\mathrm{o}}$-to- $\mathrm{C}^{\mathrm{o}}$ is triggered as a repair, as in (14c), and the enclisis we find in this example is accounted for.

Téoles tayaes [*Les teo]

have1SG-themCL cut

'I have them (my hands) cut.'

[Álvarez, Llames]

(14) a. $\left[\mathrm{CP}\left[\mathrm{C}^{\circ}\left[\mathrm{TP}\right.\right.\right.$ les $_{[\text {ENCLITIC }]}\left[\mathrm{T}^{\mathrm{o}}\right.$ teo ... les tayaes $\left.\left.\left.]\right]\right]\right]$

b. $\quad *\left[\mathrm{CP} \operatorname{les}_{[\text {ENCLITIC }]}\right]-$ ruled out by $(11)$

c. $\quad\left[\mathrm{CP}\left[\mathrm{C}^{\mathrm{o}}\right.\right.$ teo $\left[\mathrm{TP}\right.$ les $_{[\mathrm{ENCLITIC}]}\left[\mathrm{T}^{\mathrm{o}}\right.$ teo $\ldots$ tayaes $\left.\left.\left.]\right]\right]\right]-$ last resort $\mathrm{T}^{\mathrm{o}}$-to- $\mathrm{C}^{\mathrm{o}}$ as a repair

Differently from Rivero's analysis of enclisis, Barbosa $(1995,2000)$ does not argue that $\mathrm{T}^{\mathrm{o}}$-to- $\mathrm{C}^{\mathbf{o}}$ movement is the last-resort operation triggered by the phonological filter in (12).

Rather, she contends that this filter instructs and forces the derivation to pronounce a lower copy of the clitic. For illustration, consider (6), repeated in (15), which Barbosa derives as in (16).

El xenru matóse nun accidente na mina

the son-in-law killed3SG-rflCL in-an accident in-the mine

'His son-in-law got killed in an accident in the mine.'

[González, Comedies] 
(16) a. $\quad[\mathrm{CP} / \mathrm{TP}$ el xenru [CP/TP se mató se ... nun accidente na mina] $]$

b. $\quad[$ IntP el xenru $] \varphi[$ IntP se mató ... ] $\rightarrow$ illicit structure (cf. (12))

c. $\quad$ [IntP se mató se $] \rightarrow$ Pronounce lower copy $\rightarrow$ PF-convergence ensured

As illustrated in the derivation in (16), Barbosa claims that the clitic raises from a lower position and adjoins to the verb as in (16a). Once the structure is mapped onto Intonational Phrases (IntPs), the clitic ends up being the first element in an Intonational phrase, an illicit structure given the filter in (12), and the derivation is therefore instructed to pronounce a lower copy of the clitic as a repair, as in (16c), which accounts for the enclisis observed in this instance.

However, contrary to fact, these analyses predict that only a proclitic pattern be found in the finite subordinate environment, a point to which I turn next.

\subsection{A wrong phonological prediction: Enclisis in finite embedded contexts in Asturian}

The phonological filters that Rivero, Campos, and Barbosa propose to account for enclisis in matrix environments as those in (11) and (12) predict that this clitic pattern should be unattested in the finite embedded context. Consider now the examples in (17) and (18),

a. Digo [qu'ayúdame] say1SG that-help3SG-IND- meCL

b. Digo [que me ayuda] say1SG that meCL help3SG-IND

'I say that s/he helps me out.'

[From Viejo (2008)]

Yera tan pija [que llamábenla Bambi] [*la llamaben] was3SG so preppy/posh that called3PL-IND-herCL Bambi

'She was so preppy/posh that they used to call her Bambi.'[From TV Series "El Chigre”]

Given that the complementizer que "that" in the sentences above instantiates $\mathrm{C}^{\mathrm{o}}$ - for Rivero and Campos - and it would presumably be the first element of the Intonational Phrase that includes the clitic - for Barbosa, the filters proposed (11) and (12) should be rendered inert and only proclisis as in (17b) should be attested, contrary to fact. Further, the fact that only enclisis is grammatical in (18) remains unexplained.

In the next section, I lay out my assumptions and the analysis I propose to account for enclisis and proclisis alternations in Asturian both in the matrix and in the subordinate environment. 


\section{$4 \quad$ Main assumptions and analysis}

The analysis I developed in Fernández-Rubiera (2014) relies on three main assumptions: The Topic nature of preverbal non-quantified subjects in Asturian, the status of clitics as agreement $\mathrm{X}^{\mathbf{0}}$ morphemes in this language, and Rizzi's (1997) Finiteness ${ }^{\circ}$ as a phase-head (cf. Chomsky 2008). I review the arguments for each of these assumptions next.

\subsection{Preverbal Subjects, Clitics, and Finiteness ${ }^{\circ}$ as a phase-head}

First, I will assume in line with Barbosa (1995) and Alexiadou and Anagnostopoulou (1998) that the verbal head in Asturian bears $[+\mathrm{D}]$ features that may check $\mathrm{T}^{\mathrm{o}}$ 's [EPP] feature by virtue of raising to $\mathrm{T}^{\mathrm{o}}$, as shown in the schematic derivation in (19) below. With (19), I will contend that preverbal subjects in Asturian instantiate either A'-moved Focus constituents or base-generated Topic constituents, as argued for European Portuguese in Barbosa (1995) and Raposo (2000).

Barbosa (1995) and Alexiadou and Anagnostopoulou (1998)

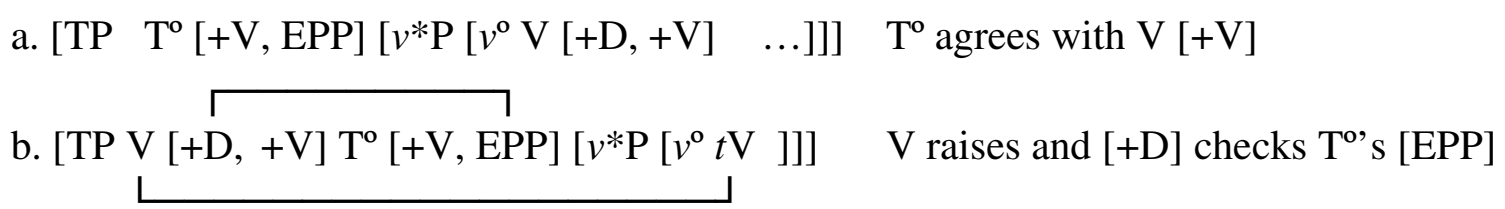

Second, I will follow Fernández-Soriano (1993, and references therein) and assume that clitics in Asturian are analyzed as $\mathrm{X}^{\mathbf{0}}$ agreement features, which are mapped in the TP-extended domain as argued in Sportiche (1996) and shown in (20) below ${ }^{4}$.

$$
\left[\text { CliticP } \text { Clitic }^{\mathbf{o}}\left[\mathrm{TP} \mathrm{T}^{\mathrm{o}} \ldots\right]\right]
$$

[Adapted from Sportiche (1996)]

4 Evidence for the $\mathrm{X}^{\mathrm{o}}$-status of clitics in Asturian comes from the ungrammaticality of interpolation in this Western Iberian language: Clitics must be adjacent to the verb, and no other element (e.g., the negative marker) may break this adjacency. Regarding the location of clitics in the phrase marker, although I do not provide any independent evidence for the mapping of clitics in a CliticP projection in the TP-extended domain, I will argue that assuming this analysis for clitics in Asturian observes two conditions: (a) this analysis captures naturally that clitics are always found in preverbal position with tensed verbs in almost all modern Romance languages, with Western Iberian languages instantiating the exception to this observation; and (b) assuming the clitic and the verb form a unit when the verb moves past the clitic, this analysis will be shown to account for enclisis/proclisis alternations without resorting to excorporation in the sense of Roberts (1991). 
Third, I will assume in line with Chomsky's (2008) phase system that both CP and $v^{*} \mathrm{P}$ are phases, "where $C$ is a shorthand for the region that Rizzi (1997) calls 'the left-periphery'" (Chomsky 2008: 143). Following Rizzi's (1997) decomposition of the CP, I assume a leftperiphery structure as that in (21).

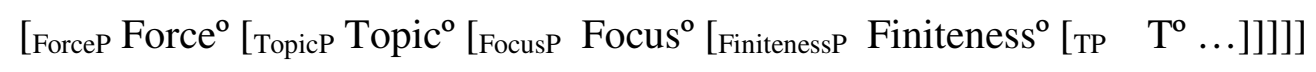

\subsection{Enclisis/Proclisis Alternations in Asturian: An Analysis}

I contend that clitic placement alternations in Asturian can be explained by assuming that Finiteness ${ }^{\circ}\left(\mathrm{Fin}^{\circ}\right)$ constitutes what Chomsky (2008) considers the CP-phase. The analysis proposed feeds from Rizzi (1997) and Chomsky (2008) and their proposals for connecting $\mathrm{C}^{\circ}$ and $\mathrm{T}^{\mathrm{o}}$ as in (22):

(22) a. For Rizzi (1997), Finiteness ${ }^{\mathrm{o}}$ shows a strong morphological connection with $\mathrm{T}^{\mathrm{o}}$.

b. For Chomsky (2008), $\mathrm{T}^{\mathrm{o}}$ inherits its agree $(\varphi-)$ and probe (EPP) features from $\mathrm{C}^{\circ}$.

I argue that $\mathrm{Fin}^{\circ}$ is a phase-head (cf. Chomsky 2008) which observes the condition stated in (23). I contend that the proposed edge condition of Fin ${ }^{\circ}$ can be satisfied either by an element undergoing $\mathrm{A}^{\prime}$-movement to the left-periphery passing through [Spec, FinP], or by the closest available head in the structure moving to Fin ${ }^{\circ}$.

(23) In Asturian, Fin is a phase-head with an edge condition which triggers and ensures the displacement of an element.

As I will show next, this analysis allows me to account for enclisis/proclisis alternations in Asturian not only in the matrix environment, but also for the position of the clitic we find in the finite subordinate context.

\section{Enclisis/Proclisis Alternations in Matrix Contexts and the Role of Fin ${ }^{\circ}$ as a Phase}

As I showed in section 2.1 above, enclisis arises in the matrix environment in Asturian in verbinitial contexts, after preverbal non-quantified subjects and with Clitic Left-Dislocated Topic constituents. Proclisis, on the other hand, shows up with the negative marker, and preverbal $w h$ and Focus constituents. I will show in the following sections how the analysis I propose accounts for the clitic pattern we find in each of these instances. 


\subsection{Enclisis in Matrix Contexts and the Edge-Condition of Fin ${ }^{\circ}$}

I contend that in the absence of A'-movement or a closer head to Fin $^{\circ}$ than $\mathrm{T}^{\mathrm{o}}$, the edge condition I propose for $\mathrm{Fin}^{\mathrm{o}}$ in (23) forces $\mathrm{T}^{\mathrm{o}}$ to raise as last-resort to $\mathrm{Fin}^{\mathrm{o}}$ picking up the clitic(s) on its way up and accounts for the enclisis we find in these instances. Consider a verb initial context as that in (24), which I analyze as in (25) ${ }^{5}$.

Téoles tayaes [*Les teo]

have1SG-themCL cut

'I have them (my hands) cut.'

[Álvarez, Llames]

[FinP teoles Fin $^{\circ}$ [CliticP tee les [TP tee ... tayaes]]]

If preverbal non-quantified subjects are Topic-like elements as I argued in section 4.1, the enclisis we find with both a preverbal subject in (26) and a Clitic Left-Dislocated structure in (27) is amenable to the same analysis under the following terms: if both preverbal subjects and Clitic Left-Dislocated Topics are base-generated in preverbal position and not derived as instances of $\mathrm{A}^{\prime}$-movement ${ }^{6}, \mathrm{~T}^{\mathrm{o}}$ raises to Fin ${ }^{\circ}$ to license its edge condition and enclisis arises as a result. The details are shown in the derivations (28) and (29) for the sentences in (26) and (27) respectively.

El xenru matóse nun accidente na mina
the son-in-law killed3SG-rflCL in-an accident in-the mine

'His son-in-law got killed in an accident in the mine.'

[*Se mató]

[González, Comedies]

5 As the reader may observe in the derivation in (25), a caveat is in order at this point. Clitic ${ }^{\circ}$ is closer to Fin $^{\circ}$ than $\mathrm{T}^{\mathrm{o}}$, so one may wonder why $\mathrm{T}^{\mathrm{o}}$ and not $\mathrm{Clitic}^{\mathrm{o}}$ must raise to Fin ${ }^{\circ}$ to satisfy its edge-condition proposed in (23). Two different approaches may adduce to account for it: Either the clitic is a "morpho-phonological deficient" element of sorts and thus not a suitable element to license Fin's edge-condition, plausibly related to the analysis of clitics as $\mathrm{X}^{\mathbf{0}}$ Agreement that I entertain, or the clitic occupies a "criterial" projection in Clitic ${ }^{\circ}$ and is frozen in place (cf. Rizzi 2007 for "criterial freezing"), preventing it from subsequent movement to Fin ${ }^{\circ}$. Since either of these two proposals would prevent the clitic from moving further up in the structure, I leave this discussion here open for future research.

6 If Topic elements are indeed base-generated and not derived as an instance of A'-movement, they should not be subject to the $w h$-island constraint. As the examples in (i) and (ii) below show, this prediction is borne out.

(i) El xenru nun sé [ónde se mató]

The son-in-law not know1SG where rflCL killed3SG

'I do not know where his/her son-in-law got killed'

(ii) Eso, yo nun sé [por qué lo sabes]

That I not know1SG for what itCL know2SG

'That, I do not know why you know it' 
(28) [TopicP el xenru ${ }_{[+T o p]}\left[\right.$ Topic $^{\circ}\left[+\right.$ Top] $\left[\right.$ FinP matóse Fin $^{\circ}$ [CliticP mató se [TP mató ...]]]]]

(29) [TopicP esO $_{[+\mathrm{Top}]}\left[\mathrm{Top}^{\circ}[+\mathrm{Top}]\left[\right.\right.$ FinP sábeslo Fin ${ }^{o}$ [CliticP

\subsection{Proclisis in Matrix Contexts and the Edge-Condition of Fin ${ }^{\circ}$}

Proclisis on the other hand is analyzed as a result of satisfying the edge condition of Fin ${ }^{\circ}$ in (23) either by the movement of a closer head to Fin $^{\circ}$ than $\mathrm{T}^{\mathrm{o}}$, as I claim to be the case with the negative marker, or by A'-movement passing through [Spec, FinP], as I claim to be the case of both wh- and Focus constituents. Consider now the effect of the negative marker, which correlates exclusively with a proclitic pattern as in (30).

Nun me mancó $\quad$ [*mancóme]
not meCL hurt3SG
'S/he didn't hurt me.'

[Orton, Mayordomu]

Following Zanuttini's (1997) analysis of the negative marker in different Romance languages, I assume that the negative head is licensed in a NegP projection that takes TP as its complement. Putting together the NegP and the analysis of clitics I entertain, the resulting structure is shown in (31). I claim that for a sentence as that in (30), the negative head is closer to Fin $^{\circ}$ than $\mathrm{T}^{\mathrm{o}}$, and thus it raises to Fin ${ }^{\circ}$ to license the edge condition of this phase head and this $\mathrm{Neg}^{\mathbf{o}}$-to-Fin ${ }^{\mathbf{o}}$ movement explains the proclitic pattern we find in this case. The derivation for (30) is shown in (32).

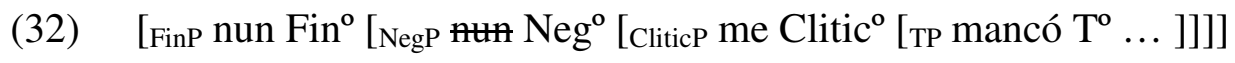

Turning now to (33) and (34), I follow Rizzi (1997, 2004) and assume that both Focus and $w h$-constituents target [Spec, FocusP] in order to license their [+Focus] criterial features. I argue that these elements reach this position by virtue of passing first through [Spec, FinP]. This intermediate step licenses the edge condition of $\mathrm{Fin}^{\circ}$ and explains the proclisis we find in (33) and (34) as in (35) and (36) respectively.
Cómo t'atreves?
[*atréveste]
how rflCL-dare2SG
'How dare you?'

[Rodríguez Medina, Gaviotes] 
Yo MESMA me la repito un cientu vegaes [*repítomela]

I self rflCL-itCL repeat $1 S G$ one hundred times

'I myself repeat it to myself one hundred times.'

[de Pablo, Memoria]

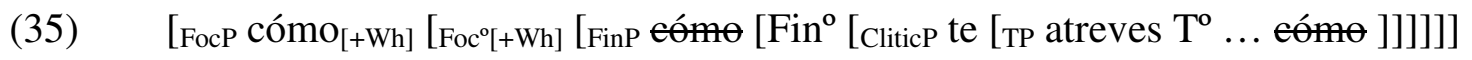

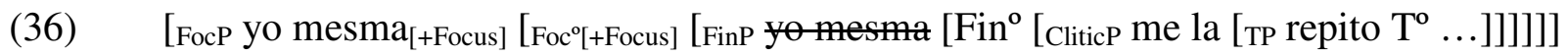

Next, I will discuss how the different clitic patterns we find in the finite embedded contexts can also be accounted for on the analysis I propose of Fin ${ }^{\circ}$ as a phase-head with an edge condition.

\section{Enclisis/Proclisis Alternations in the Finite Embedded Contexts: que1 and que2}

Demonte and Fernández Soriano (2009) argue that the complementizer que 'that' can appear in different heads in the left-periphery in Spanish (Sp). Using as evidence what is standardly called recomplementation patterns - an example in (42), these authors claim that the two que complementizers instantiate a que 1 in Force ${ }^{\mathrm{o}}$ and a que 2 in Fin ${ }^{\circ}$. Thus, the embedded clause in (37) receives the analysis in (38).

Dijo que a ese empleado que no sabía cuánto le pagaban said3SG that to that employee that not know3SG how-much himCL paid3PL 'S/he said that s/he didn't know how much they paid that employee.'

(38) Demonte and Fernández Soriano (2009): Recomplementation

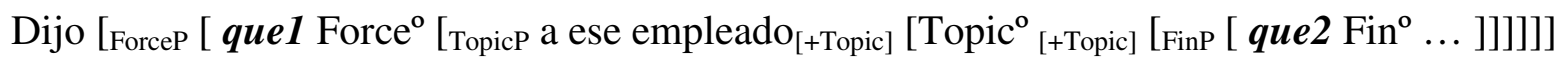

Following Demonte and Fernández Soriano's (2009) analysis for Spanish, I extend it to Asturian and I argue that this language also exhibits a quel in Force ${ }^{\circ}$ and a que 2 in Fin ${ }^{\circ}$, as illustrated in (39).

$$
\left[\text { ForceP }\left[\text { que1 } \text { Force }^{o} \ldots\left[\text { [FinP }\left[\text { que2 } \text { Fin }^{\circ} \ldots\right]\right]\right]\right]
$$

In order to account for the enclisis/proclisis alternations we find in the finite embedded context in Asturian, I will argue that assertive predicates (cf. Hooper and Thompson 1973, Bosque 1990, among others) such as digo 'I say' may select either Force o or Finiteness'. In line with the complementizer system in (39), selection of Force ${ }^{\circ}$ is mapped as quel and selection of Fin(iteness) $)^{\circ}$ as que2. Consider now the data in (40): 
a. Digo [qu'ayúdame]

say1SG that-help3SG-IND- meCL

b. Digo [que me ayuda]

say1SG that meCL help3SG-IND

'I say that s/he helps me out.'

[From Viejo (2008)]

If Force ${ }^{\circ}$ mapped as a que 1 is selected by the matrix predicate digo 'I say', $\mathrm{T}^{\mathrm{o}}$-to-Fin' ${ }^{\mathrm{o}}$ is triggered in the absence of $A^{\prime}$-movement or a closer head that may satisfy the edge condition of Finiteness ${ }^{\mathbf{o}}$ in (23). The enclitic pattern we find in (40a) is therefore derived as in (41).

Digo [ForceP [quel Force ${ }^{o}$ [FinP [ ayúdame Fin $^{\circ}$ [CliticP ayuda me [тр ayuda ... ]]]]]]

On the other hand, if Finiteness ${ }^{\circ}$ mapped as a que 2 is selected, I contend that merging this complementizer in Fin ${ }^{\circ}$ licenses the edge condition of this phase head, blocks $\mathrm{T}^{\mathrm{o}}$-to-Fin ${ }^{\mathrm{o}}$ and explains the proclitic pattern we find in (40b) as in (42).

Digo [FinP [ que2 Fin $^{\circ}[$ CliticP me [TP ayuda ... ]]]]

Summarizing, entertaining that enclisis/proclisis alternations arise as a result of the phase-properties of Finiteness ${ }^{\circ}$ allows me to account for these alternations as follows. An enclitic pattern obtains in the absence of $\mathrm{A}^{\prime}$-movement or a closer head to $\mathrm{Fin}^{\circ}$ than $\mathrm{T}^{\mathrm{o}}$, which raises to satisfy Fin's ${ }^{\circ}$ edge condition and triggers enclisis as a consequence. Proclisis obtains either when there is a closer head to Fin $^{\circ}$ than $\mathrm{T}^{\mathbf{o}}$ or when an element undergoes $\mathrm{A}^{\prime}$-movement to the leftperiphery of the clause, in which cases $\mathrm{T}^{\mathrm{o}}$-to-Fin ${ }^{\mathrm{o}}$ is not triggered and consequently a proclitic pattern is observed. This analysis has been not only shown to account for clitic placement alternations in the matrix environment, but also in the finite embedded one: if que may appear in either Force ${ }^{\mathbf{o}}$ or Finiteness ${ }^{\mathbf{o}}$ in an articulated left-periphery, the position that the complementizer occupies naturally captures whether enclisis obtains (i.e., with Force's complementizer que1) or proclisis (i.e., with Finiteness ${ }^{\circ}$ 's complementizer que2). Further evidence for the analysis proposed will be discussed next, namely the different pragmatic interpretations that enclisis/proclisis alternations give rise to in the finite embedded context, and the exclusive enclisis and interpretation we find with consecutive clauses.

\section{$7 \quad$ Further predictions and evidence}

Entertaining that different selection patterns and consequently different (but homophonous) complementizers are at play when accounting for the clitic pattern we find in the finite embedded context will be shown to naturally capture (a) the interpretation differences that selection of Force $^{\mathbf{o}}$ and of Finiteness ${ }^{\mathbf{o}}$ give rise to in the finite embedded context in Asturian, and (b) the 
exclusive enclisis and the interpretation it generates with consecutive clauses. These two predictions are discussed next.

\subsection{Pragmatic $\left[ \pm\right.$ conviction] and selection of Force $^{\circ}$ or Finiteness ${ }^{\circ}$}

Viejo (2008) and Fernández Rubiera (2009) show that enclisis/proclisis alternations in finite embedded contexts as those in (40) correlate with different interpretations. Enclisis is reported to give rise to an interpretation that marks the content of the embedded clause as part of the belief state of the matrix predicate's subject or the speaker, what I call a [+conviction] pragmatic interpretation. Consider the example in (43). A fragment that cancels the [+conviction] interpretation of the content in the embedded clause that shows enclisis as that in brackets is perceived as pragmatically inadequate.

Digo qu'ayúdame

[\#pero nun toi seguru]

[+conviction]

say1SG that-help3SG-IND-meCL but not am sure

'I say that s/he helps me, \#but I am not sure (that s/he does help me).'

In contrast with (43), the fragment in brackets is not perceived as pragmatically inadequate when the embedded clause shows proclisis as in (44), entailing that when the embedded clause exhibits proclisis, it encodes a [-conviction] pragmatic interpretation.

Digo que me ayuda [pero nun toi seguru] [-conviction] say1SG that meCL help3SG-IND but not am sure

'I say that s/he helps me, but I am not sure (that s/he does help me).'

If the different clitic patterns in (43) and (44) relate to the selection of Force ${ }^{\mathrm{o}}$ or Finiteness $^{\mathbf{o}}$ respectively and the position that the different que complementizers occupy in the structure, the different pragmatic [conviction] readings we find with enclisis and proclisis in the examples above can be naturally accounted for by the analysis I propose. I contend that selection of Force ${ }^{\circ}$ mapped as que 1 correlates with a [+conviction] interpretation, whereas selection of Finiteness ${ }^{\circ}$ mapped as que 2 gives rise to a [-conviction] interpretation.

Putting together the position of the quel and que 2 complementizers and the edge condition of Fin $^{\circ}$ I propose in (23), the different clitic patterns and interpretation differences we observe in (43) and (44) can be captured as shown in the structures in (45) and (46) respectively. 


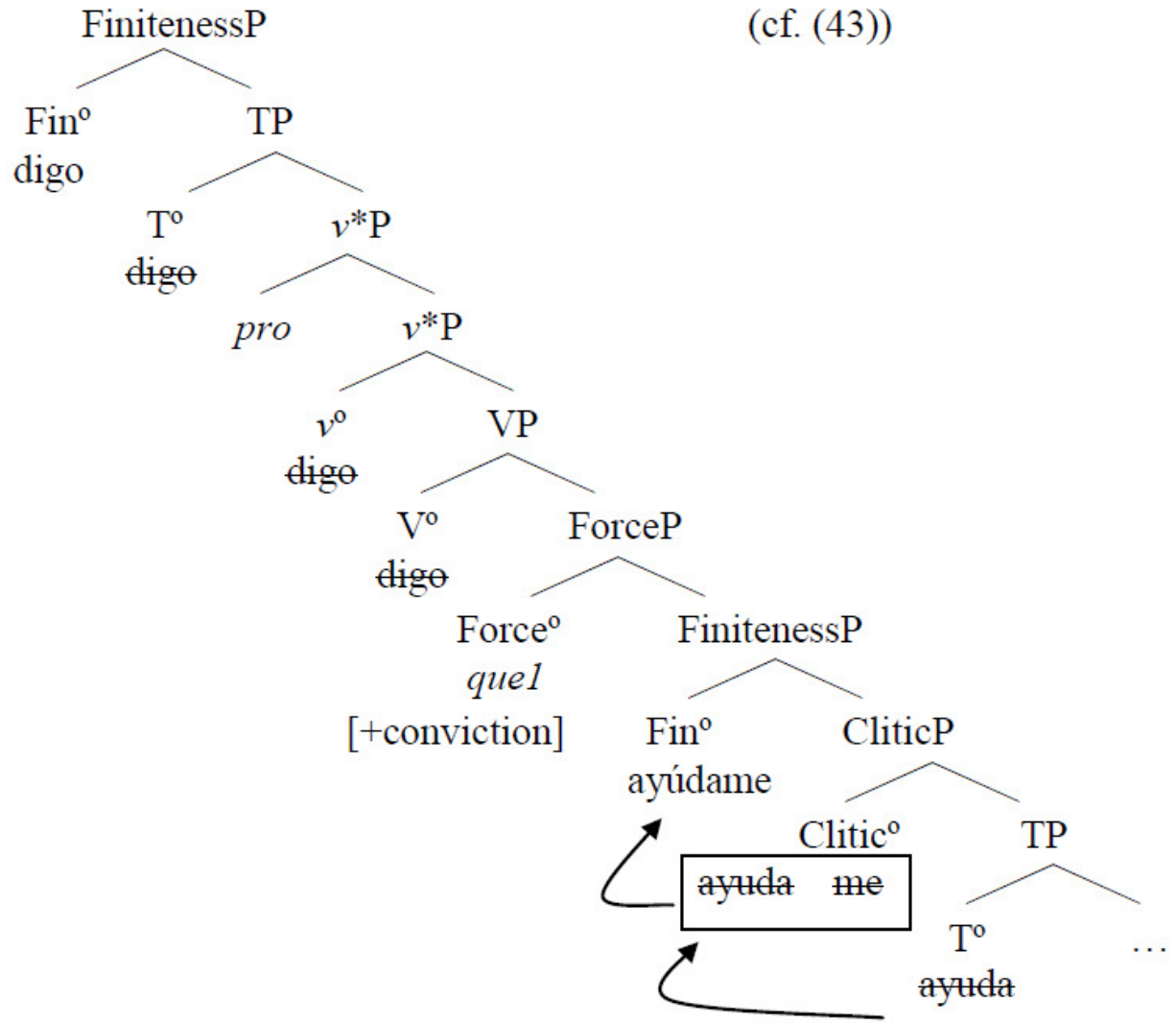

(46) FinitenessP

(cf. (44))

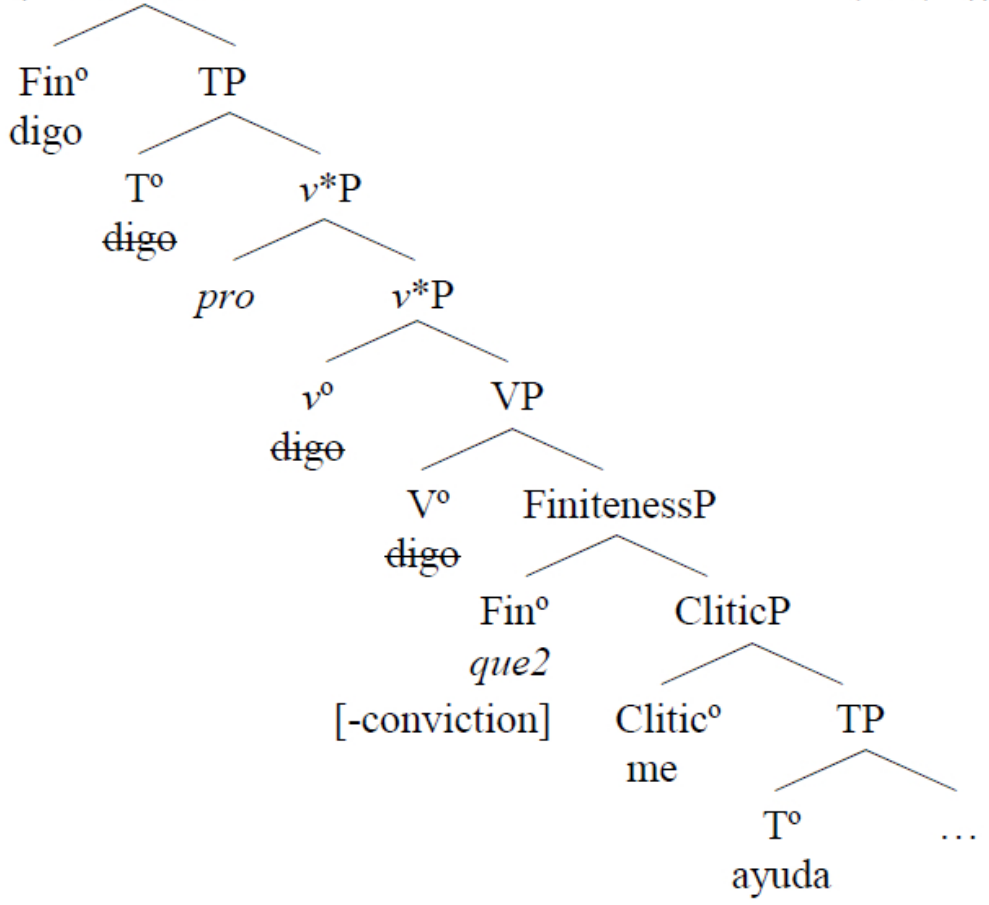


A second piece of further evidence, the structure and interpretation of consecutive clauses, is discussed next.

\subsection{Consecutive Clauses and Exclusive Selection of Force ${ }^{\mathrm{o}}$}

If que instantiates two different but homophonous complementizers mapped in Force ${ }^{\circ}$ or in Finiteness ${ }^{\circ}$ in the left-periphery of the clause, quel and que 2 respectively, we would expect to find examples in which only Force ${ }^{\circ}$ quel is realized. I claim that this is indeed what we find in consecutive clauses, a relevant example below:

Yera tan pija [que llamábenla Bambi] [*la llamaben] was3SG so preppy/posh that called3PL-IND-herCL Bambi

'She was so preppy/posh that they used to call her Bambi.'[From TV Series "El Chigre”]

On the analysis I propose, the que complementizer we find in consecutive clauses as that in (47)instantiates exclusively Force ${ }^{\circ}$ and que1. The enclitic pattern arises as a result of the Fin's edge condition in (23) triggering last-resort $\mathrm{T}^{\mathrm{o}}$-to -Fin ${ }^{\circ}$ movement in the absence of $\mathrm{A}^{\prime}$ movement passing through the embedded [Spec, FinP] or a closer head to Fin ${ }^{\circ}$ than $\mathrm{T}^{\mathrm{o}}$. The details for (47)are shown in the structure below.

Yera ta pija ...

was $_{3 S G}$ so preppy/posh

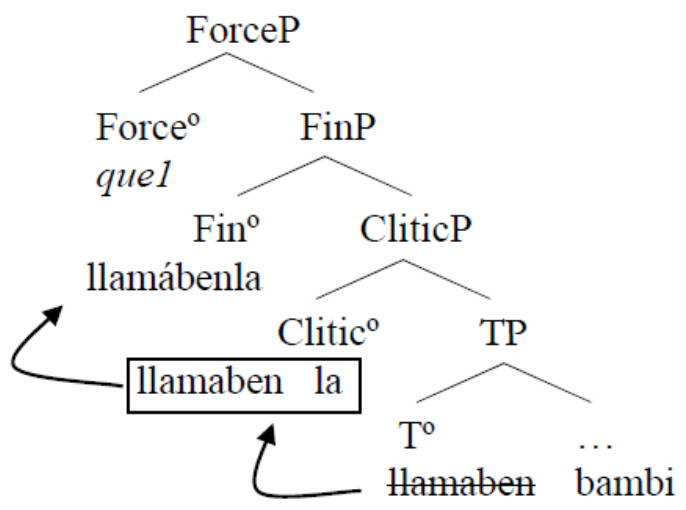

Furthermore, if consecutive sentences as that in (47) instantiate exclusively quel, we would expect that only a [+conviction] interpretation be readily available. The inadequacy of the fragment in brackets in (49) indicates that this is indeed the case.

Yera tan pija que llamábenla Bambi, [\#pero nun la llamaben asina] was3SG so preppy/posh that called3PL-IND-herCL Bambi but not her called that-way 'She was so preppy/posh that they used to call her Bambi, \#but they didn't call her that.' 


\section{Conclusions and further questions}

In this paper, I have presented in section 2 different matrix environments where enclisis and proclisis alternations are observed in Asturian, and I discussed in section 3 how previous analyses relying on phonological filters have accounted for these alternations, concluding that none of them predict the availability of enclisis in the finite embedded context, a clitic pattern that can be found in Asturian.

In order to account for enclisis and proclisis alternations in Asturian, I have argued in section 4 for an analysis in terms of Rizzi's (1997) Finiteness ${ }^{\circ}$ (Fin') being a phase-head (cf. Chomsky 2008) with an edge condition, a condition that can be satisfied either by an element undergoing A'-movement to the left-periphery of the clause or by the closest available head in the structure. As I showed in section 5, enclisis obtains in the absence of A'-movement or a closer head to Fin $^{\circ}$ than $\mathrm{T}^{\mathbf{o}}$. Proclisis shows up on the other hand under two circumstances: either there is an element undergoing A'-movement to the left-periphery, which passes through [Spec, FinP] and licenses Fin 's edge-condition, as I claim to be the case of $w h$ - and Focus constituents, or there is a closer head to $\operatorname{Fin}^{\circ}$ than $\mathrm{T}^{\mathrm{o}}$, as I argue to be the case of the negative marker.

Extending Demonte and Fernández Soriano's (2009) analysis of the complementizer system in Spanish to Asturian, I have shown in section 6 how selection of Force mapped as quel explains the availability of enclisis in the finite embedded context: similarly to matrix environments, $\mathrm{T}^{\mathrm{o}}$-to-Fin ${ }^{\mathrm{o}}$ is triggered in the absence of $\mathrm{A}^{\prime}$-movement or a closer head. Selection Fin $^{\circ}$ mapped as que 2 on the other hand is predicted to trigger exclusively proclisis, as merger of this complementizer in Fin ${ }^{\circ}$ licenses this phase-head edge condition.

Further predictions and evidence were discussed in section 7. First, I illustrated the different interpretations that enclitic and proclitic patterns give rise to in the finite embedded context in Asturian in terms of what I call [+conviction] and [-conviction] pragmatic readings. I have shown that these different readings can be easily explained under my analysis as follows: Selection of Force ${ }^{\mathrm{o}}$ mapped as quel explains both the enclitic pattern and the [+conviction] interpretation, while selection of Fin ${ }^{\circ}$ mapped as que 2 accounts for the proclitic pattern and the [conviction] reading we find in this case. Second, I showed how the exclusive enclitic pattern we find in consecutive clauses in Asturian and the [+conviction] interpretation it gives rise to can also be accounted for with the same analysis: consecutive clauses have been argued to select exclusively Force ${ }^{\circ}$ mapped as que 1, accounting uniformly for the enclitic pattern and the [+conviction] reading.

For future research, it remains to be determined whether similar interpretation differences in the finite embedded clause can be traced in other languages, and how these may correlate with the complementizer system and its interaction with the proposed phase-status of Finiteness ${ }^{\mathbf{o}}$. 


\section{$9 \quad$ References}

Asturian Corpus Bibliography

Álvarez, Xurde. 2005. Les llames del to llar antiguu. Uviéu: Academia de la llingua asturiana. González Álvarez, Arsenio. 1997. Tres comedies. Uviéu: Academia de la llingua asturiana.

Orton, Joe. 1995. Lo que vio'l mayordomu. Uviéu: Academia de la llingua asturiana [Translation by Lluis Aique Iglesias].

de Pablo, Eladio. 1996. Memoria del llaberintu. Uviéu: Academia de la llingua asturiana [Translated by Ramón d'Andrés Díaz].

Rodríguez Medina, Pablo. 2006. Cantu de gaviotes. Uviéu: Academia de la llingua asturiana.

\section{References}

Alexiadou, Artemis, and Elena Anagnostopoulou. 1998. Parametrizing Agr: Word

Order, V-Movement and EPP-Checking. Natural Language and Linguistic

Theory 16(3):491-539.

Barbosa, Pilar. 1995. Null Subjects. PhD dissertation, MIT.

Barbosa, Pilar. 2000. Clitics: A Window into the Null Subject Property. In João Costa, ed., Portuguese Syntax: New Comparative Studies, pp. 31-93. New York: OUP.

Bosque, Ignacio. 1990. Las bases gramaticales de la alternancia modal. Repaso y balance. In Ignacio Bosque, ed., Indicativo y subjuntivo, pp. 13-65. Madrid: Taurus.

Campos, Héctor. 1989. Clitic Position in Modern Gallegan. Lingua 77:13-36.

Chomsky, Noam. 2008. On Phases. In Robert Freidin, Carlos P. Otero and Maria L. Zubizarreta, eds., Foundational Issues in Linguistic Theory: Essays in Honor of Jean-Roger Vergnaud, pp. 133-167. Cambridge, Mass.: MIT Press.

Demonte, Violeta, and Olga Fernández Soriano. 2009. Force and Finiteness in the Spanish Complementizer System. Probus 21(1):23-49.

Fernández Rubiera, Francisco J. 2009. Clitics at the Edge: Clitic Placement in Western Iberian Romance Languages. PhD dissertation, Georgetown University.

Fernández-Rubiera, Francisco J. 2013. Clisis revisited: Root and Embedded Contexts in Western Iberian. In Christine Meklenborg Salvesen and Hans Petter Helland, eds., Challenging Clitics, pp. 55-86. Amsterdam: John Benjamins.

Fernández Soriano, Olga. 1993. Los pronombres átonos. Madrid: Taurus.

Hooper, Joanne B. and Sandra A. Thompson. 1973. On the Applicability of Root

Transformations. Linguistic Inquiry 4:465-497.

Raposo, Eduardo P. 2000. Clitic Positions and Verb Movement. In João Costa, ed., Portuguese Syntax: New Comparative Studies, pp. 266-298. New York: OUP.

Rivero, Maria L. 1986. Parameters in the Typology of Clitics in Romance and Old Spanish. Language 62(4):774-807.

Rizzi, Luigi. 1997. The Fine Structure of the Left Periphery. In Liliane Haegeman, ed., Elements of Grammar: Handbook in Generative Syntax, pp. 281-337. Dordrecht, Netherlands: Kluwer Academic Publishers.

Rizzi, Luigi. 2004. Locality and Left Periphery. In Adriana Beletti, ed., Structures and Beyond: The Cartography of Syntactic Structures, pp. 223-251. New York: OUP. 
Rizzi, Luigi. 2007. On Some Properties of Criterial Freezing. In Vincenzo Moscati, ed., CISCL Working Papers on Language and Cognition, Vol. I, pp. 145-158. Siena, Italy: Centro Iterdipartimentale di Studi Cognitivi sul Linguaggio.

Roberts, Ian. 1991. Excorporation and Minimality. Linguistic Inquiry 22:209-218.

Sportiche, Dominique. 1996. Clitic Constructions. In Johan Rooryck and Laurie Zaring, eds., Phrase Structure and the Lexicon, pp. 213-276. Dordrecht, Netherlands: Kluwer Academic Publishers.

Viejo Fernández, Xulio. 2008. Pensar asturiano. Ensayos programáticos de sintaxis asturiana. Uviéu: Trabe.

Zanuttini, Raffaella. 1997. Negation and Clausal Structure: A Comparative Study of Romance Languages. New York: OUP. 